University of Louisville

ThinkIR: The University of Louisville's Institutional Repository

Electronic Theses and Dissertations

1931

\title{
The vitamin B content of kale greens.
}

Virginia Lee Smith

University of Louisville

Follow this and additional works at: https://ir.library.louisville.edu/etd

Part of the Food Chemistry Commons, and the Nutrition Commons

\section{Recommended Citation}

Smith, Virginia Lee, "The vitamin B content of kale greens." (1931). Electronic Theses and Dissertations. Paper 1955.

https://doi.org/10.18297/etd/1955

This Master's Thesis is brought to you for free and open access by ThinkIR: The University of Louisville's Institutional Repository. It has been accepted for inclusion in Electronic Theses and Dissertations by an authorized administrator of ThinkIR: The University of Louisville's Institutional Repository. This title appears here courtesy of the author, who has retained all other copyrights. For more information, please contact thinkir@louisville.edu. 


\title{
UNIVERSITY OF LOUISVILLE
}

THE VITAMIN B CON TENT OF RALE OREENS

\author{
A Dissertation \\ Submitted to the Faculty \\ of the araduate School of the College of Liberal Arte \\ In Partial Fulfiliment of tho \\ Requirements for the Degree \\ of Master of seience
}

Department of Chem1etry

By

Virginia Lee Bmith 
INTRODUCTORY

HISTOR ICAL_-

EXP ER IMENTAL_-_._.

SUMM ARY

REFEREYCES--.-_-_- 60 
INTRODUCRORY 
Then listing groens for a spocial diot, the genoril custom is to name splnach. Experimenturs havo used spinach in cotorminirg the vitumin contont of a groen.

There is ereen on the market known as kalo, which 1s preferted by reny becauso of 1 ta more palatable flavor. If kale woro glven a full recognition on a diot list as oplnech, it vould bo consumed in groater quantitie because of ita more fevorcble flavor, thereby accomplishing the purpose of the speclal alet more effectiveity.

That kale 18 cons mod in great quantities and must ve in Eeneral favor with the publio is evicionced by the roport of the following wolesale produce dealer of Loulavilie, Kantuoky.

Tho Unitod froduce Corpeny, Loulsv112e. Kentucky, otates "h fufr usthmte would bo thit thore are about fivo hundrod anc lifty barrels por cay, overy day in the jenr recalved in Louloville".

Stinson ke kartin, Louloville, Kentucky state, "The amount of bile groens sold in Loulsvillo from January flrat to July first totals 1500 buskels da11y." 
P. G. Helmerdinger, Loulsv1110, Kontucky reports, "The total for the year 1s ebout one hundred and ninetythree (193) corloads with an average of elght hunared (800) bushola per oar or a totwl of one hundred and fiftyfour thrusand four hundred $(254,400)$ busheas whioh are sold through this market and consumed in Loulsvillo and nearby terretory."

- The mineral content of kalo groens versus spinach 1a quoted below as given by Lary Swartz fose:

$\begin{array}{lccc} & \text { Dalolum } & \text { Dhospitorous } & \text { Iron } \\ & \text { Shares } & \text { Shares } & \text { Sheres } \\ \text { Splnaoh } & 12.22 & 6.48 & 30.12 \\ \text { Kale } & 40.08 & 5.93 & 26.09\end{array}$

Vitamin A Vitamin B Vitanin C splasen $\quad++t+t+$ Kalo ? $?$

The caloium contant of kely is som to bo over three thmes the amount prosent in aplraoh one the phosplorous and irph antent fall only a fow polnte below spinaoh. Thus fer kale compares favorably with spinach.

The purpose of this experiment as presented in this thesis is to dotermine the vitamin B oontent of Kale as oompared wth the vitamin B content of spinach. 
IIISTORICAL 
"It is now well estabilahed the $t$ what in the pest hes been called vitamin $B$ is not an entity, but comprises more than one nutritionally ossential subatanco."l

Various writers from time to time, and notably Mitcholl (1919) in a orition alsoussion, called attention to the fact that not ill of the published evidence was consistent with this simplifylib assumption; but only slowly (slowly at least as tilings go in the raplaly noving history of the vitamins) did there aocumulate such a preponderáne of experimental evidence for the multiple nature of vitamin $B$ as to commend the univeranl acoptance of the students of this problem.

Emmett and Luros, in $1920^{2}$, reported the results of aystematic 1nvostigation in whioh ldentical food matorinls wore fed for the prevention of polynouritis In pigeons and for tho support of frowth in rats. Furthermore, these comparstive feeding experiments were repeated with portions of the same food meterials whioh had boen heated at different temperatures and under diffurent conditions. They conoluded thet the ant1nouritic vitamin soomea to be lass stable to heat and alkali thin the rat-growth-promoting vitamin.

Fund nna Dubln, in $1921^{3}$, reoorded very briefly some experiments upon fretional adsorption which lod 
them to belleve that autolyzed yoast contelned two witer soluble vitamins, of whlah the antinouritio was the more easily odsorbod by fuller's enth.

Levono and whfold $(1923)^{4}$ found ovidenoe of the multiple nature of vitamin B in the feot thet their oxperiments upon the ooncentrution of this factor resulted In altering the relative antinouritio and Erowth-promoting activitios of their matoriala.

Kinnersley nd leters (19:5), wo also were workInE primarily from the point of view of isolation of the antineurltic vitamin, reported the seperation of a nlghIy untinouritio substance wilch did not osuse increase in tho weight of plgoons aftor oure of the polynour1tio aymptoms. This was interpreted as supportine the view of the caltiple nature of vitarin $B$.

In the anto year, $t$ is vien was alscussed tontatively by hecollum, Stramonds and Beoker $(1325)^{5}$.

In $1926^{6}$, Haue and Carriok puolished furthor ovidenoe of tho fact that antineuritio and growth-promoting potenoles do not almys run parallol, na in the ame year the subjoct was greotly clarifled by throo contributions from the united states publio lloalth servioe and two from the laboratory of hocollum, all of whioh enpinsize the important fact that the erowti of rets (and there is no rouson to dout tilet this 18 true of marnicils cencrelly) roquires both the antinourltio and an ther, more heat-stable substunco whlch along with 
the antineuritio subst nce had hitherto beon covered by the term vitamin $B$.

In the course of an investigation begun a study of the influence of dietary deflciencles upon oxperimentel tuberoulosis in the elolno ret, Smith and llendrlok $(1926)^{7}$ found thet a diut oontaining 40 per oent of rollod oets, wh thequate amounts of casein, salts, and vitam in containing fats, wa not adoqueto to oupport normal erowth f youne rats; but bocamo so whon oupplesented by yeast wh Ion had autooluved for six hours at rifteon pounds pressure, prooodure belleved to destroy the antineuritio vitamin of the yoast and, furthermore, that nelther autocleved yoat alone nor seldell vitamin B picrate sone wuld meat the Erowth-promoting vitomin B requirement of rats; but thet they supplemented unch other in suca away that toget they met this vitamin B requirement. Th1s work of Smith and hendrick was immedietely confirmed by soldell (1926) who, as the result of experiments with both rats uni pigeons, suggested that ruts (and probably other mamals) noud both the entinour1t1c aublance and the ot ior, more hat-atablo fector of vitamin $b$, willo pigeons need only the ant1nour 1tio vitamin; and lor thia reason he reoomended that the rat be used for determinations of vitumin $B$ arid the pigeon, on account of its simpler noeds, for 
the studies of the antineuritio vitanin.

Closely following the oontrioution of Smith and liondriok, eppored the indepandent ane prootloglly - Imultanoous wrk of Coldbereer, theeler, L11lie and kogers $(1926)^{9}$ who found a similar supplementery relationsilp in meeting the growth requirements of young rats, betwoen eutoclaved yenst (as the source of the heat-atable factor) and alcohol-extruct of corn meal (as the source of the antinouritic substence). Inis work wes discussed in 1 ts bearings ujon otrer invostigations of coldberger and his asociates upon human pellagre and the more or less analogous oondition known a black-tongue in doga. Colabergar end tenner $(1225)^{10}$ had postulated the oxistenoo of previously unreoognized detary feotor concernod in the prevention of pellagra (tentatively designated as the "P-P factor" or "pellegra-preventing v1trin"), and this was now held to be lcontion with the hast-stablo fector of vitamin $B$, the rets whose rations lecked tils fector being coaorlbed by Goldberger, hineuler, L1111e and hogers ${ }^{9}$ a developlng a pellagra-I1ke condition after about nine weoks or this dietary deprivation. Hoanwllo Laird (1926), In hocollum's laboratory, found in the testing of numerous extrects ootalned from naturil foods by means of different (usually acidulated) 
solvents, repested instances in which antireuritic and Erowth-promotine jotencies did not run parallel, and some cases in whloh growth was rot pronotod by elther of the extreots but wa Indueed by a mixture of them. salmon $(1927)^{11}$, working with soy beans end velvet beans and Ith the leaves of volvet beand and of rape, found thet the seods woro roletivaly moro potant for the provention of polynouritis and tho laves for tho promotion of erowth. Le also described e pertial a paration upon luller's easth. The aicohol-extreat, in the form of a water solution, was treated for the removal of ether-80luble substances and of eubatances preolpitablo by load nootete, before the troatment with fullor's earth. The leaves were extracted wt aclulutod water instead of alcohol. Ihe continuation of this work has been desoribed in inter peper by salmon, Guerrant and likys $(1927)$, who roport thet fuller's ourth adsorbs both faotora; but, uncer certalr conaltions, tho ontinouritic wore completely. They describe the preparation, from velvet bean 16ives, of a fruction protionlly freed from the antineuritic out stili rich in tho other fuctor. Leanwh1le chick and rosoce $(1927)^{12}$ reported serles of experiments in which varlous oxtracts and preperations of youst and of whent embryo were fod aingly and in combination wita results lon demonstratod st111 furthor tho ex istenoe in tho vitain B oomplex of more than one factor ussontial to growth; und Ilassan and 
Drumrond $(1927)^{13}$, in the course of stuay of the posolble relation between vitemin b end protein motebolism, independently obtained evidence of the presunce of two growth-prowoting faoto's in whet hed beon known as vitamin b.

The work of rolmer and Kennedy $(1927-1928)^{14}$, while chlefly presented from somewhat different angle, seome also to furnish a lirge anount of evidence of the multiple neture of vitemin $B$. İvans and Burr $(1928)^{15}$ have recontly furnishod a oleer-out domonstretion.

v111nms and vatormen $(1927-1928)^{16}$ hold that v1tanin is is of a tripartite nsture, involvine tho ent1nourlt1c factor required by both rats und pleons, second fretor required by rata.

Fvidence of more quentitative neture was obtalned by Sherman and txtmayor (1927), who moasured, by neans of the avorages of lirgo numbers of quantitatively conduoted foeding oxperinonts, th relative richness, in the two factors required by rets, of wholo woat on the one hend and of milk or of eutoclaved yeast on the other. Ihnt nesting in the eutoclave mey destroy the antineuritio potenay of yeast whlle lesving it ot1ll a bood source of the other factor had been shown oy previous workers... The present invest1tation established 
a marked supplomentary relationship between whit and milk, wheat belng relotively roner in the antineuritio, and milk relatively richer in the more hoat-stable factor. This work thus furnishod a basis for the quantitative reinvestigation of the previously rocordod "vitamin B values" of foods.

Hunt $(1928)^{17}$ found oorn (ma1ze) to be very sim1lar to wheat in 1 ts content of the two factors required for growth of rata.

Eddy $(1927,1928)^{18}$ found that the previously reported low vitamin B value of cooked or canned spinach Is due to pauclty of the antinouritio factor in a materlal relatively rich in the more hoat-stable vitamin; and also that bananas are rolatively $r$ oh in the more heatotable vitamin thin in the antinouritio factor.

llogan and luntor $(1928)^{19}$ have very recont 1 y reported thet just as by heating the antineuritio factor can be more or 108:3 solectively destroyed, so the more heat-strble factor my bo selootively destroyed by exposure to ultraviolot Irradiation.

Horeover a lood which is a good $\mathrm{s}$ xiroe of both mey at1ll be markedly richer in one than the other, as the investigations above cited have shown to be true in the case of milk, and of typlcal seods and green leaves. Mllk and green leaves, good sources of both these factors, are relatively richer in the more heat-stable 
factor. Thole grain cerenls and legumes, falr-to-good sources of both factors, are relatively rloher in the antineuritio vitamin. Thus both milk and groen leaves hore show valuable auplementary rolationship to soeds with respoot to vitamin B, a had prevlously been sown to bo the onse with rospoct to vitamin $A$.

The disoussion of the evidenoe of the multiplo nature of vitamin $B$ has involved empiesis upon the fact the heating in the autoclave deatroys the antineur't10 vitamin wat not the other frotor, and sonsoquently frequent references to the latter as tire more hoat-stable feotor have beon mede. This fact might readily tend to give an exaggerated Impression of the susceptibility of the antineuritic vitamin to destruction upon heating.

Someth1ng should therefore be seid of the quantitative studies of the stablilty or labllity of the antinouritic aubatanco, beasuse of the nutritional signliglonnoe of this property in rolation to vitamin values of foods willoh have boen heated or stored under different conditions.

In dry state, at practioaliy noutral reaction, the antinouritio vitamin is quite steblo to heating at $100^{\circ}$, showing no mossurable destruction or ineotivation ofter 48 hours of such heating; whereas the same meterlal hested in water for 6 hours at $100^{\circ}$ showed a slight dininution 
of potency (Sherman and Spohn, 1923). Alt ough th1s work was dono before the differentiation of tho vitamin B complex, it is cortain that it wa the antinouritic substenoe whose stabllity was measurod, both because tho so-oallod antipollogris vitamin is so much zore stablo and booguse the work of shermen and fxtmayer he shown plainly that cor's milk is rioher in this vitamin than In the antineur 1t1c aubstance, so that the latter must have bosn tho $11 m i t i n g$ factor in the rat frowth oxperIments of Sherman and Spoin.

In other exiriments (Sherman and Grose, 1923; Sherman and Burtis, 1926) ${ }^{26}$ the rete of destruction of "v1tamin B" was mensured nt different tempereturos at a fixed temperature of heating of $100^{\circ}$. While it has not jet been shown whother the ent1neurit1c substanoe is the limiting fector of the vitamin $B$ caplex of tomato juioe, yet in view of the much groeter stability of tho other vitamin, it oeoms prootionlly certuin that the experiments hero olted may be taken as affording at least approxisate messures of the rate of destruction or Inativetion of the antinouritic vitamin under the conditions described.

The development of rethode for the seprirate quantitative measurement of values of foods as sources of the two separate factors 18 now well sadvanoed. 
Foods whloh, by means of rat fooding experiments, heve boon shown to be good sources of vitamin $B$ as previously understood are, therefore, now soen to be good soureas of both the antineuritic substance and the more hoat-stable vitamin.

If, on the other hand, the food, when tested for undifferentiated vitamin $B$, has not given good results, it $1 \mathrm{~s}$ not necossar1ly poor in both of these essontiale, but may concelvably be a cood auroe of one or the other of them, and should therefore, be teated for ocoh separately.

"Thus the multiple naturo of vitamin B is established by en abundance of evidence, and ovidence of several different klnde.

"It no longer appoar profitable to perform oxperiments or to publish papers in which vitamin B (In the sense in which the cerm has hitherto been used) 1s treated as an entity." 1 
EXPERINFNTAL 
The experimente ware onducted according to the mothod of Shorman and Machthur 20 as follows: Joblthy, young rets of known nutritional history were placed at 24 to 30 days of age and welghing gonerally from 50 to 60 ersme in wire cugas yroveded wh soreon bottoms and Given a vitam in froe diet with water ed I1bitum. The laborntory tochnique was that of Forry 23 (1) The rats wero welghod weekly and the weights and history of each animal were recorded in a loose leaf notebook. (2) Tho food wns mado ints soft paste to prevent sonttering and (3) the cages wore sturlilized wookly. Pater was given by an Inverted bottle with gluss tube which projocted into the inside of the cace. The dutios of $t$ is experinent were carried out on suncings and hollans as regulariy as on week days.

The kale was purchased prosh on the market dally and Sroshly cooked loaves were piepared dully by thoroughly washine and oooking in a 810 so beaker 25 with onough adoltional watar to prevent stiokint; just prior to fooding. The time of cooking was roculs tod by the tonderness of the ereens, usually abait 15 minutes. The da1ly amount of frosh troen kale fed each andmal varled from $0.2 \mathrm{gram}$ to $1.0 \mathrm{gram}$ dilly. 
The objeot of using cooked kele instead of the raw leaves was to discover the vitamin $B$ potenoy of the foodstuff in question as it is consumed by the individual.

hale and fomalo rots wore used interchangesbly in this determination of vitamin $B$ olnse the average difference in weights of the two is so small as to bo nogliglblo acoording to the statement of sherman and Burt1s 26.

DINS The bast 1 det contained oasein 19, atoroh 63, salt sixture $4^{(a)}$, buttor 10, agar agar 2 and cod livor 0112 perts. Tre basal diet was adjusted to acommodete supplerents for the fractional deteralnation of vitamin $B$ acoording to the diets of $c$. Il. flunt ${ }^{17}$. The supplements to the basal diet ware: whols, coaxsoly ground wheat (b) as the source of vitamin $D$ (Sherman's thermo-1ab1le, ant1nouritio factor of $B$ ) and auto-claved yenst ${ }^{(0)}$ as the source of vitamin a (Shorman's thermo-stablo, ant1pollagrio vitanin and solaberger's $P-P$ frotor of vitamin B.) Sherwan's nomonalature, vitamin $F$ ana vitamin a w11l be used to designsto the frootions of vitamin $B$ in this work.

Kale greene of unknown vitamin B content were comblned with the basal diet in such a manner as to stuay 1t as a probable source of the vitamin $F$ and $a$ faotors of vitamin D colbined as a source of vitamin F elone 
17

and as a sourco of vitamin $G$ alone accoralnb to diet \#1 and 4, 5, 6 respectively as shown in tablo 1 . 'íwo - ontrola wore onducted: first, oannod spinaoh of known vitari in 3 contont 21 was supplemonted in tha basal diet In the seme mannor as kalo cooording to dlots "2, 10 ana 11 rospectively as shown in tablo 1 , and second; yeast form tablet plus the basal dlet aosording to diat 3 und wole whont supplecented by auto-clavad yeast as in det $\# 9$ aocording to table 1. 
a) Osborne anc Mendel salt Wixture: 24

\begin{tabular}{|c|c|c|c|}
\hline $\mathrm{CaCO}_{3}$ & & 134.8 & \\
\hline $\mathrm{HgCO}_{3}$ & & 24.2 & \\
\hline $\mathrm{Na}_{2} \mathrm{CO}_{3}$ & & 34.2 & \\
\hline KI & & 0.020 & \\
\hline $\mathrm{K}_{2} \mathrm{CO}_{3}$ & & 141.3 & \\
\hline $\mathrm{H}_{3} \mathrm{PO}_{4}$ & & 103.2 & \\
\hline $\mathrm{HCl}$ & & 63.4 & \\
\hline unsO $_{4}$ & & 0.079 & \\
\hline $\mathrm{H}_{2} \mathrm{SO}_{4}$ & & 9.2 & \\
\hline c1trio nold & $\mathrm{H}_{2} \mathrm{O}$ & 111.1 & \\
\hline Fo oltrate & $1 \frac{1}{2} H_{2} \mathrm{O}$ & 6.34 & \\
\hline $\mathrm{NaF}$ & & 0.248 & \\
\hline $\mathrm{KSI}\left(\mathrm{SO}_{4}\right)_{2}$ & & 0.245 & \\
\hline
\end{tabular}

Mixed of refully and dried at $100^{\circ} \mathrm{C}$ for threo hours in en electric oven with intermittant stirring.

b) Vhole whoat coarsley ground was obtalned from a rellable whole-grain house, D. Lubber's, Broadway, Loulso11le, Kentucky.

o) The yeast foam tablets voro obtainod from Northwestern Yoast Company, $1750 \mathrm{~N}$. Ashland Avo., Chloago, Illinols. To auto-olave, the yeast was plscod in onatel pans to deptin of about $\frac{1}{8}$ lnoh and auto-olaved for 4 hours at 15\# steam pressure. 
DESCRIPTION OF DIETS

\section{Table 1}

Diet \#1

Diet $\$ 2$

Diet \#3

Diet \#4

Diet \#5
Cooked kale greens plus basal diet.

Experimental

Studied as the probable source of both the

$F$ and $G$ factors of vitamin $B$

Canned Spinach plus basal diet

Control

Poodstuff of known vitamin B content ${ }^{21}$ ready

cooked as source of both $F$ and $Q$ factors

of vitamin $B$

Yeast foam tablets plus basal diet

Control

a second fodstuff of known vitamin B content as aroe of both $F$ and $G$ factors of vitamin $B$ Cooked kale greens plus basal diet

Experimental

A seoond experimental kale diet run to observe the growth ourve during summor months as compared with diet \#l run during winter months. Kale greens plus cracked whole wheat plus basal diet Experimental

Unkenown vitamin content supplemented by $F$ factor present in whole wheat. An attempt to discover the supplementery factor in kale. 
Table 1

(Continued)

Diet \#6

Cooked kale greens plus auto-claved yeast

plus basal diet

Experimentel

Unknown vitamin content supplemented by the

G factor of vitamin $B$

Di et $\# 7$

Cracked whole whoat plus basal diet

Control

To observe growth curve when only F factor

of vitamin B is present in the diet.

Diet $\# 8$

Auto-claved yeast plus basal diet

Control

To observe growth curve when only a factor

of vitamin B is present in the diet.

Diet \#9 Cracked whole wheat plus auto-claved yeast

plus basal diet

Control

Supplemented ration.

To observe growth curve of normel vitamin

B content.

Diet \#10 Cooked spinach plus auto-olaved yeast plus

basal diet

Control

Comperison of growth curves of kale with

spinach when supplemented with $G$ fraction.

of vitamin $B$ 
DESCRIPTION OF DIETS

Table 2

(Continued)

Diet \#11 Cooked spinach plus whole wheat plus basal

diet

Control

Comparison of growth curves of kale and

apinach when supplemented with $F$ factor

of vitamin B 


\section{D1et \#1}

Cooked Kale Groens and Basel Dlot

\begin{tabular}{|c|c|c|}
\hline Casein & 1.0 & ams \\
\hline Butterfat & 0.75 & $n$ \\
\hline Staroh & 2.8 & $n$ \\
\hline Salt mixture & 0.2 & $n$ \\
\hline Cooked kale & 0.25 & $"(1 \mathrm{gm} \cdot 12 / 11 / 28)$ \\
\hline Total & 5.00 & $m$ \\
\hline
\end{tabular}

Experimental Perlod

November 5, 1928 - January 5, 1922

Weighto of Experimental Animals

Nov. 5, Rat + Rat $^{\delta}$ Rat $q$ Rat 9 Rat $q$ Rat $\delta$ 1928 \#1048 \#1050 \#1065 \#1066 \#1062 \#1067

\begin{tabular}{rrrrrrrr}
\hline Nor. 5 & 25.5 & 34.3 & 49.2 & 33.0 & 21.5 & 44.4 \\
" 10 & 35.5 & 42.4 & 62.25 & 40.75 & 41.5 & 53.4 \\
" 17 & 43.25 & 43.8 & 54.4 & 42.5 & 45.0 & 57.4 \\
" & 24 & 43.0 & 49.4 & 62.5 & 45.5 & 47.4 & 54.1 \\
Dec. 1 & 41.9 & 48.0 & 55.0 & 45.0 & 46.8 & 53.0 \\
" & 8 & 42.0 & 50.0 & 52.0 & 47.8 & 45.0 & 52.6 \\
" 15 & 38.4 & 49.0 & 52.5 & 40.4 & 35.5 & 45.5 \\
" 22 & 45.0 & 53.5 & 69.0 & 43.0 & $412 / 16 / 2847.8$ \\
" 29 & 49.0 & 55.5 & 66.0 & 43.0 & & 45.5 \\
Jan. 5 & 43.0 & 55.5 & 60.0 & 41.0 & & 46.0
\end{tabular}




\section{HISTOKY OF FATS ON DI EI \#2 \\ Cooked Kalo Oreens and Basal Dlet}

The rats on tinls diet booame lesa ative, fur ruffled, but otherwise normal aftor one woek on the oxperimental diet. They had developed no onuffles nor lazy motions of any one member of the body. Second and third weeks rets apeared the same and normally active. veek of $11 / 24 / 28$-- 12/1/28 rats ate about one-tialf of their rution. Fron $12 / 1 / 28$-- 12/5/28 rats bocame fractlous, snappy and fur stringy. ill ratw on tis det bogan to show typlcal symptom of polynouritis $(26)$ at $t$. date. Rat H1062, 12/6/28 lload rotracted. 12/13/28 spest1c galt, hend retraoted. 12/15/28 Cartwheol, drags hind $10 \mathrm{~g}$ and hows convulsive selzures when handlod. 12/16/28 died. (Only animel lost in the group of six animels over an oxparimental period of 9 woeks.)

The romaining rats in the group suffered signs of polynour t1a, but never appeared in them as severely as In \#1062. The consumption of food varled from $1 / 2$ to $1 / 3$ ration remelning with 1088 and less food une ten at olose of experimental period.

1/6/29 Experimental perlod closed.

Fur moother altho still yellow and stiff. Futs were nervous and undersized. In proportion to the length of the body, these animals had smaller chests und showed a tendenoy to hive longer leg bones relativelto their 
body length than did the animals on control diot \#3 of the oamia ge. llowever, these rats ourvived wide range of temperature a shown in following tempereture chart. 
TERPLRATURE KFADINOS

\begin{tabular}{lll} 
Dete & AM ${ }^{\circ} \mathrm{C}$ & ${ }^{\circ}{ }^{\circ} \mathrm{C}$ \\
\hline & & \\
\hline Nov. 23 & 10 & 19 \\
24 & 10 &.- \\
25 & 18.5 & 15 \\
26 & 15 & 18.5 \\
27 & 15 & 17.5 \\
28 & 17 & 17 \\
29 & 16 & -17 \\
30 & 17 & 17 \\
1 & 18.5 & 17 \\
2 & 11 & 15.5 \\
3 & 18.5 & 22 \\
4 & 19 & 22 \\
5 & 17 & 21 \\
6 & 15 & 20 \\
7 & 15 & 20 \\
8 & 20 & 16 \\
9 & -- & 15 \\
10 & 14.5 & 19 \\
11 & 14 & 20 \\
12 & 20 & 24 \\
13 & 20 & 21 \\
14 & 19 & 24 \\
15 & 20 & 18 \\
16 & -- & 17 \\
17 & 11 & 21 \\
18 & 18 & 21.5 \\
19 & 17.5 & 21 \\
20 & & 21
\end{tabular}




\section{Diot $\# 2$}

Canned Splnaoh and Basal Dlot

\begin{tabular}{|c|c|c|c|}
\hline Casein & 1.0 & grams & \\
\hline Butterfat & 0.75 & $n$ & \\
\hline Staroh & 2.8 & $n$ & \\
\hline Salt mixture & 0.2 & $n$ & \\
\hline Canned Spinaoh & 0.25 & " $11 \mathrm{gm}$. & $12 / 11 / 28)$ \\
\hline Total & 5.00 & grame & \\
\hline
\end{tabular}

Experimental period

November 5, 1928 - January 5, 1929

Volehts of Experimental Animale

$\begin{array}{lllll}\text { Rate } \hat{\delta} & \text { Rat } q & \text { Rat } \hat{\delta} & \text { Rat } \hat{\delta} \\ \# 1052 & \# 1053 & \# 1054 & \$ 1060\end{array}$

\begin{tabular}{lllll}
\hline Nov. $5 \cdot 28$ & 52.5 & 34.0 & 38.0 & 50.5 \\
" 10 & 60.4 & 40.4 & 41.8 & 59.8 \\
" 17 & 53.5 & $41 / 16 / 28$ & 34.4 & 59.0 \\
" 24 & 61.1 & & 38.7 & 55.8 \\
Doc. 1 & 60.4 & & 35.7 & 53.3 \\
" 8 & $46.0^{*}$ & & $33.0^{*}$ & $48.5^{*}$ \\
" 15 & & & \\
" 22 & & & & \\
" 29 & & &
\end{tabular}


HISTURY OF RNTS ON DTFT \#2

Cannod Splnach plus Basal Llet

These rets became lesa active, fur ruffled, but otherwise normal after one weok on experimental diet. liad developed no snuffles nor lazy motions of any one mexiber of the body.

Typloel polynour1tio condit lons developed one weok eariler $(11 / 24 / 28)$ than thoy oocurred in the rats on diet $/ 11$. 12/6/28 rat $/ 1060$ developed lazy movements and hunched baok. 12/8/28 hat \#1060 nose blaed. 11/16/28 hat \#1053 dled. (Autopsy showed gas in intest1nos). 12/8/28 - 12/10/28 rats $\# 1052,1054$ and 1060 died. Showed general loss of welght with mis-shapen bodies and convulsive selzures and artwheol, spastio galt eto., as rat $\$ 1062$ on diet $\# 1$. $1 / 5 / 29$ close of experimental perlod. All ratw on this alet ded of polynouritis at olose of 5th experimental week. 


$\begin{array}{ll}\text { Caseln } & 1.0 \mathrm{gram} \\ \text { Butterfat } & 0.75 " \\ \text { Starch } & 2.8 " \\ \text { Salt m1xture } & 0.2 " \\ \text { Yoast } & 0.25 "(1 \mathrm{gm} .12 / 11 / 28) \\ \quad \text { Total } & 5.00 \mathrm{grams}\end{array}$

Uelghts of Experimental D1ete

\begin{tabular}{|c|c|c|c|c|}
\hline Date & $\begin{array}{l}\text { Fiat of } \\
\# 1056\end{array}$ & $\begin{array}{l}\text { Hat ô } \\
\# 1057\end{array}$ & $\begin{array}{l}\text { Rat } f \\
\# 1059\end{array}$ & $\begin{array}{l}\text { Rat }+ \\
\# 1061\end{array}$ \\
\hline Nor. $6 \cdot 28$ & 30.0 & 52.0 & 30.0 & 28.5 \\
\hline " 20 & 37.4 & 60.8 & 33.5 & 34.4 \\
\hline " 17 & 43.0 & 60.7 & 41.8 & 37.4 \\
\hline Doo. 1 & 63.2 & 83.8 & 57.4 & 53.7 \\
\hline$" 8$ & 77.0 & 97.0 & 47.0 & 63.0 \\
\hline " 15 & 92.0 & 105.3 & $12 / 9 / 28^{*}$ & 63.0 \\
\hline " 22 & 98.0 & 110.0 & & 66.0 \\
\hline " 29 & 104.0 & 129.0 & & 69.0 \\
\hline Jan. 5 & 113.0 & 141.0 & & 81.0 \\
\hline
\end{tabular}


IISTOKY OF WNS ON DIET \#3

Yoast plus Basal Diot

Snufilos and loss of wolght (temperature).

vontrol animale - normal albino rats in appearanoa and activity.

- weak - forepewa and nose bleeding preceding day. 


\section{D1ot \#4}

Kale Greens and Basal Diet

\begin{tabular}{|c|c|c|}
\hline Casein & 1.8 & grams \\
\hline Staroh & 6.0 & $"$ \\
\hline Salt hixture & 0.4 & $n$ \\
\hline Buttorfat & 1.0 & $"$ \\
\hline Agar hear & 0.1 & $n$ \\
\hline Cod Liver oll & 0.2 & $"$ \\
\hline Kale Greone & 0.5 & $r$ \\
\hline Total & 10.0 & grums \\
\hline
\end{tabular}

Wo1ghts of txperimental Animala

\begin{tabular}{|c|c|c|c|}
\hline Ley & 18,129 & 37.5 & grams \\
\hline & 20 & 45.5 & $n$ \\
\hline & 25 & 67.0 & $n$ \\
\hline June & 1 & 72.0 & $"$ \\
\hline & 7 & 75.0 & $"$ \\
\hline$n$ & 17 & 69.0 & " \\
\hline & 23 & 72.0 & $"$ \\
\hline July & 1 & 81.0 & $\pi$ \\
\hline
\end{tabular}


HISTOKY OF HIS ON DIET \#4

Kale Greans plue Basal Diot

Very slight nouritio condition observod.

Rat wa luas nervous, larger, eleoker, whitor fur with koon eyes. 


\section{Diet \#5}

Kale Groens and Whole whent and Basal Dlet

\begin{tabular}{|c|c|c|}
\hline Casein & 1.8 & 3ram \\
\hline Starah & 4.0 & $n$ \\
\hline Salt mixture & 0.5 & $n$ \\
\hline Butter fat & 1.0 & $n$ \\
\hline Cod Liver 011 & 0.2 & $n$ \\
\hline Whole Theat & 2.5 & $"$ \\
\hline Kalo Groens & 0.5 & $"$ \\
\hline Toted & 20,0 & an \\
\hline
\end{tabular}

Exporimontal forlod - 4/29/89 - 6/8/29

We1ghts of Exverimental Animale

\begin{tabular}{|c|c|c|c|c|c|}
\hline Date & $\begin{array}{l}\text { Rat } \hat{0} \\
\# 1206\end{array}$ & $\begin{array}{l}\text { Rat } q \\
\# 1207\end{array}$ & $\begin{array}{l}\text { Rat } \\
\# 1208\end{array}$ & $\begin{array}{l}\text { Rat } q \\
\# 1209\end{array}$ & $\begin{array}{l}\text { Kst } \\
\# 1210\end{array}$ \\
\hline $4 / 29 / 29$ & 74.5 & 76.5 & 48.0 & 44.0 & 51.5 \\
\hline $5 / 4 / 29$ & 97.5 & 95.0 & 75.5 & 72.5 & 78.5 \\
\hline $5 / 11 / 29$ & 106.0 & 108.7 & 87.0 & 84.3 & 92.2 \\
\hline $5 / 18 / 29$ & 119.0 & 118.0 & 102.5 & 95.5 & 106.5 \\
\hline $5 / 25 / 29$ & 131.0 & 118.0 & 117.0 & 107.5 & 119.0 \\
\hline $6 / 1 / 29$ & 133.5 & 120.0 & 123.0 & 114.0 & 125.0 \\
\hline $6 / 8 / 29$ & 162.0 & 142.0 & 147.0 & 133.0 & 154.0 \\
\hline
\end{tabular}


Kalo Oroens plus Craoked thole Whoat plus Basel Dlot

Rats in this group ate $1 / 2$ food fed first weok. Second week - 5/16/29 11ttle food remelned. 5/18/29 on no food remalned. These rata romelned normal in appearenoe and activity.

1. Dur slook.

2. Koen ojos.

3. sctive.

4. Proper proportion.

5. No deatha. 
Diot \#6

Kalo Greons and futo-claved Yeast ond Basal

Diet

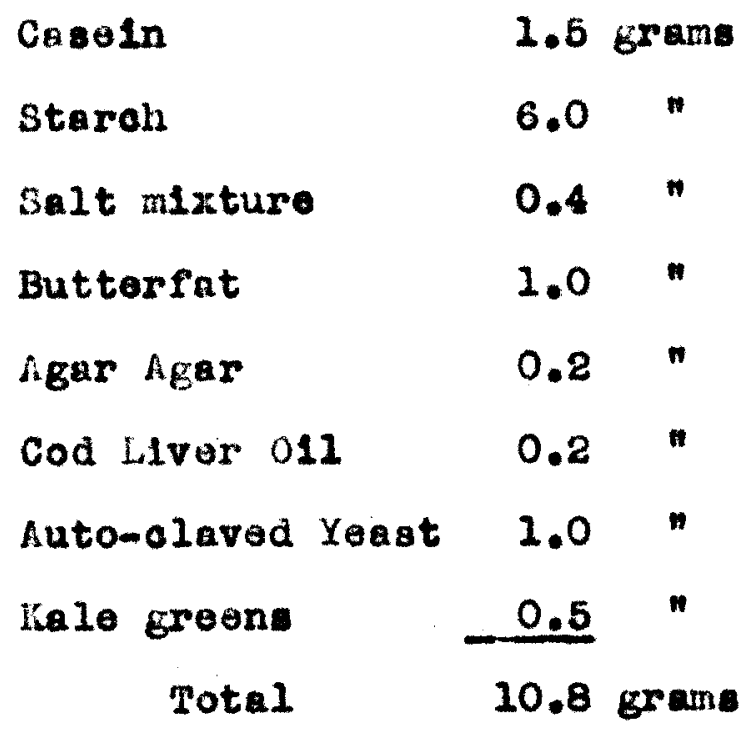

Experinental fer1od - 4/29/29--6/8/29.

\section{Velghte of Experimental Animale}

\begin{tabular}{|c|c|c|c|c|c|}
\hline Date & $\begin{array}{l}\text { Rat } q \\
\text { \#1201 }\end{array}$ & $\begin{array}{l}\text { Rat } \% \\
\text { I1202 }\end{array}$ & $\begin{array}{l}\text { Rat } q \\
\# 1203\end{array}$ & $\begin{array}{l}\text { Rat } 9 \\
\# 1204\end{array}$ & $\begin{array}{l}\text { Rat } \hat{\delta} \\
\# 1205\end{array}$ \\
\hline $4 / 29 / 29$ & 43.2 & 32.4 & 55.0 & 69.7 & 68.0 \\
\hline $5 / 4 / 29$ & 56.2 & 49.0 & 70.5 & 81.5 & 96.0 \\
\hline $5 / 11 / 2 \theta$ & 50.0 & 46.0 & 66.0 & 73.5 & 94.0 \\
\hline $5 / 18 / 29$ & 45.0 & 46.5 & 56.5 & 64.0 & 85.0 \\
\hline $5 / 25 / 29$ & 43.0 & 46.8 & 55.0 & 54.7 & 84.0 \\
\hline $6 / 1 / 29$ & 44.0 & 50.5 & 58.0 & $44.5^{*}$ & 86.0 \\
\hline $6 / 8 / 29$ & 45.0 & 54.5 & 64.5 & & 83.0 \\
\hline
\end{tabular}


Kale Greene plus Auto-olaved Yeest plus Basel Dlet

One-half food eaten first week. By the third weok no food remained. By fourth wook $(5 / 16 / 29)$ rats beoame slightly week, although, otherwiso normal in appearance. 5/27/29 conditi on weaker, fur stringy and all food enten. 6/2/29 Group muoh wakor with rats \#1:02, \#1203 and \#1204 drage Ing hind loge wa oonvulsive solzures when handiod. 6/3/29 \#1204 died previously nervous, snappy, stringy fur, weak, slow motion, legs longer in proportion to leneth of body. 


\section{Diet \#7}

Whole Wheat and Besel Diet

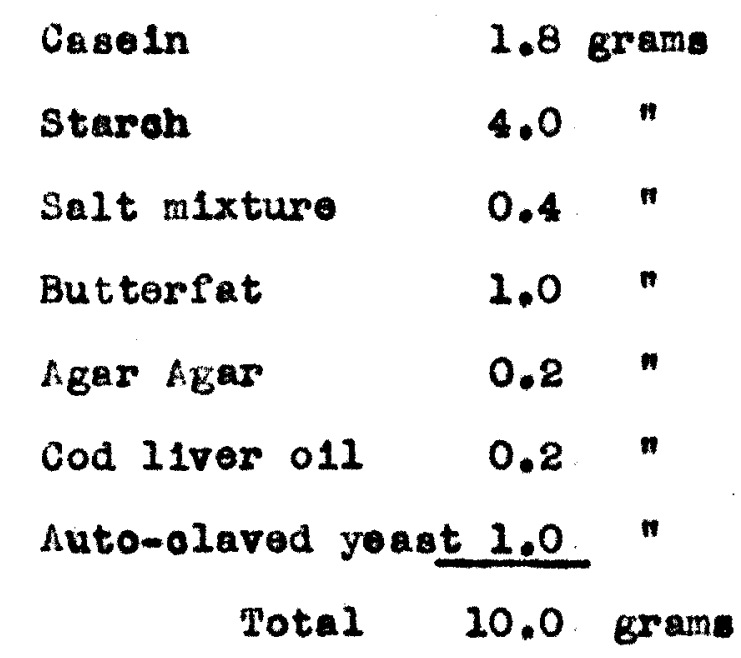

Experimental Perl od -- 4/29/29-6/8/29

\begin{tabular}{|c|c|c|c|c|c|}
\hline Date & $\begin{array}{l}\text { Fat } \hat{\delta} \\
\$ 1211\end{array}$ & $\begin{array}{l}\text { Rat } \hat{\sigma} \\
\text { \#1212 }\end{array}$ & $\begin{array}{l}\text { Rat } 9 \\
\# 1213\end{array}$ & $\begin{array}{l}\text { Rat } \\
\text { \#1214 }\end{array}$ & $\begin{array}{l}\text { liat } \\
\not 1215\end{array}$ \\
\hline $4 / 28 / 2 \theta$ & 29.8 & 32.0 & 71.5 & 59.0 & 68.5 \\
\hline $5 / 4 / 29$ & 49.0 & 48.6 & 88.0 & 85.0 & 95.8 \\
\hline $5 / 11 / 29$ & 65.7 & 61.0 & 106.5 & 82.0 & 108.0 \\
\hline $5 / 18 / 20$ & 79.0 & 73.6 & 125.0 & 104.5 & 121.0 \\
\hline $5 / 25 / 29$ & 96.0 & 86.5 & 122.5 & 112.5 & 132.5 \\
\hline $6 / 1 / 29$ & 102.0 & 96.0 & 122.0 & 118.0 & 138.0 \\
\hline $6 / 8 / 29$ & 122.0 & 115.0 & 141.0 & 136.0 & 158.0 \\
\hline
\end{tabular}


HISTORY OF GiTS ON DIET \#7

Whole Pheat plus Basal DLet - - - -

Firat two wooks $1 / 2$ food eaten - by tild weok

al1 eaten.

6/16/29 Rate all normal in appearanoe

$5 / 27 / 29$ "

6/2/29 Galn in welght, oyes not olear, not

normally active. 
D1ot \#8

Auto-Claved Yoest and Basel Dlot

$\begin{array}{lcc}\text { Casein } & 1.0 & \text { gram } \\ \text { Staroh } & 6.3 & " \\ \text { Salt nuxture } & 0.4 & " \\ \text { Butterfat } & 2.0 & " \\ \text { Agar Agar } & 0.2 & " \\ \text { Cod 11ver o11 } & 0.2 & " \\ \text { Auto-olaved yeast } & \\ \text { Total } & \frac{1.0}{10.0} \text { gram }\end{array}$

Bxper1mental yerlod - 4/29/29-6/7/29

Velght of Experimental Animela

Date

Ret 9 int 0

Rat 9

$\# 1216$ \#1217 \#1218 \#1219 \#1220

\begin{tabular}{llllll}
\hline $4 / 29 / 29$ & 41.0 & 67.0 & 57.8 & 24.0 & 33.5 \\
$5 / 4 / 29$ & 54.0 & 88.5 & 76.6 & 32.5 & 45.8 \\
$5 / 11 / 29$ & 54.5 & 94.0 & 78.5 & 26.5 & 45.0 \\
$5 / 18 / 29$ & 47.5 & 81.5 & 76.0 & $*$ & 39.0 \\
$5 / 25 / 29$ & 37.5 & 75.0 & 67.5 & & $*$ \\
$6 / 1 / 29$ & 1 & 69.0 & 66.0 & & \\
$6 / 7 / 29$ & & 58.0 & 62.5 & &
\end{tabular}


HISTOKY OP WM OH DIHT $\$ 8$

- nuto-claved Yeast plus Basal Dlet

III food eaten by seoond wook $(5 / 10 / 29)$

Rat \#1219 runt.

Fat \#1219 diod - slok woakling - runt.

5/16/29 11ttle food remaining.

Kat \#1216 Slightly weak, snuffles.

Rat /1217 Normel in appoaranoe.

Rat \#1220 Slightly wark.

5/22/29 \#1216 Fur stringy-thinner-weak-emaciated.

5/24/29 \#1216 Deoldely hunch bock - rlbued tall, omaciated.

5/26/29 /1216 died - nour1t1c.

$5 / 27 / 29$ \#1220 died - same history \#1216

Three 10s8es. 
Diet $\$ 0$

Cracked Whole theet and futo-claved Yeast and Basel

piet

\begin{tabular}{|c|c|}
\hline Casein & 1.8 \\
\hline Starch & 4.0 \\
\hline Salt mixture & 0.5 \\
\hline Butterfat & 1.0 \\
\hline Agar hgar & 0.2 \\
\hline Whole Whuet & 2.5 \\
\hline Auto-claved yeast & 0.4 \\
\hline
\end{tabular}

Experimentel period: 5/25/29 - $7 / 8 / 29$

heights of Ixperimentel Rats

Dete

Rat o Rat $q$

\#1221 \#1222

$5 / 25 / 29$

45.5

54.0

$6 / 1 / 29$

$61.0 \quad 54.0$

$6 / 7 / 29$

$73.5 \quad 80.0$

$6 / 17 / 28$

$106.0 \quad 93.0$

$6 / 23 / 29$

114.597 .0

$7 / 1 / 29$

$125.5 \quad 102.0$

$7 / 8 / 20$

$130.0 \quad 107.0$ 


\section{HISTORY OF WATS ON DIET\# 8}

Cracked Thole Uheat plus Auto-claved Yougt plus Bas l D1et

fiats nomal in appearanco; oyos keen, fur slook, vory notivo and normal in $8 i_{7} \theta$. 
D1et $\$ 10$

Splnaoh and tuto-clnved Yeast and Basal plet

\begin{tabular}{|c|c|c|}
\hline Casein & 1.5 & rama \\
\hline Staroh & 6.0 & $n$ \\
\hline Selt mixture & 0.4 & $n$ \\
\hline But torfat & 1.0 & $"$ \\
\hline Cod I:ver 012 & 0.2 & $n$ \\
\hline $\begin{array}{c}\text { Ruto-claved } \\
\text { yeast }\end{array}$ & 1.0 & $n$ \\
\hline Spineoh & 0.5 & "( Iater \\
\hline & 10.6 & \\
\hline
\end{tabular}

Ex perimental Period - 6/17/29 - 8/5/29.

Velshts of Fxperimental inimals

Date

Ret $q$ Rat $q$ Rat $\hat{\sigma}$ Rat $\hat{\sigma}$

\#1284 \#1225 \#1226 \#1227

$\begin{array}{lllll}6 / 17 / 29 & 32.0 & 18.0 & 33.0 & 31.0 \\ 6 / 24 / 29 & 45.0 & * 6 / 20 / 29 & 44.0 & 45.0 \\ 7 / 1 / 29 & 49.0 & & 46.0 & 49.0 \\ 7 / 8 / 29 & 45.5 & & 45.5 & 43.0 \\ 7 / 15 / 29 & 51.5 & 46.0 & 42.0 \\ 7 / 22 / 29 & 48.5 & & 48.0 & 44.0 \\ 7 / 29 / 29 & 46.0 & & 47.0 & 45.0 \\ 8 / 5 / 29 & 44.0 & & 48.0 & 45.5\end{array}$


HISTOIY OP TETS ON DTI $\mathrm{T}$ \#10

Spinach lus futo-claved Yeast plus Basal Dlot

lst weok $1 / 2$ food egten

and week $3 / 4$ food aten

homelnoer of experimontal perlod all of food was onton.

$3 r d$ wek fur becane stringy and yollow. 311 gint symptoms of polynouritis, otherwise rats romalnod practlcally nomal until conclusion of axperinontal period. 
D1ot \#11

Spinach, thole vineat and Baeal Diet

\begin{tabular}{|c|c|c|}
\hline Casein & 1,8 & grams \\
\hline Staroh & 4.0 & $n$ \\
\hline Salt ralxture & 0.5 & $n$ \\
\hline Butterfat & 1.0 & $n$ \\
\hline Cod 11ver o11 & 0.2 & $n$ \\
\hline Vhole lheat & 2.5 & " \\
\hline Splnaon & 0.5 & $n$ \\
\hline Total & 10.5 & grame \\
\hline
\end{tabular}

ExperimentaI Perlod: 6/17/29 - 8/5/29.

Velghte of Experimentul Animaie

\begin{tabular}{|c|c|c|c|c|c|}
\hline Date & $\operatorname{liat}_{\not 1228} \delta$ & $\begin{array}{l}\text { hat } \\
\text { \#220 }\end{array}$ & $\begin{array}{l}R_{a} T \\
\# 2230\end{array}$ & $\begin{array}{l}\text { Rat } 9 \\
\# 1231\end{array}$ & $\begin{array}{l}\text { Kat } \hat{o} \\
\# 1238\end{array}$ \\
\hline $6 / 17 / 20$ & 32.0 & 29.0 & 31.0 & 33.0 & 34.0 \\
\hline $6 / 24 / 29$ & 44.0 & 46.0 & 47.0 & 39.0 & 42.0 \\
\hline $7 / 2 / 29$ & 52.0 & 50.0 & 57.0 & 42.5 & 60.0 \\
\hline $7 / 8 / 29$ & 65.0 & 66.0 & 68.0 & 47.0 & 70.0 \\
\hline $7 / 15 / 29$ & 72.5 & 78.0 & 79.0 & 60.0 & 85.0 \\
\hline $7 / 22 / 89$ & 84.0 & 86.0 & 87.0 & 78.5 & 95.0 \\
\hline $7 / 129 / 89$ & 22.0 & 95.0 & 96.0 & 87.7 & 107.0 \\
\hline $8 / 5 / 29$ & 102.0 & 105.0 & 105.0 & 97.0 & 119.0 \\
\hline
\end{tabular}


IISTORY OF HeS JN DITT $\# 21$

Spineoh jus Whole lheat plus Basal hiet

lst week $1 / 2$ food onten.

and weok all of food eaton.

iato were normol in tppactance and activity. 
UISCUSSION 
In the oxperimental work of the winter of 128 (Nov. 5, 1928 to Dec. 29, 1028) it was noted that, even tho thero wes a oudien sho wide range of temperature,27 tho experimental animals on the cooked kaja greens dot plus the besel det survived the tost porjod of nine weeks with one death oocurring in the sevonth wook.

One of the ountrol diets, canned glne plus tine bosel dot, hat one doath to oosur at the close of the flifh woek vitik no survivals at the ond of the test perlod of nine weoks. Polynourltis gyoud in both groups Ithough loes severely in the cooked balo group than tha cunned aptnach eroup.

The gronth ourve of the rats on the det contwining cooked kale ereons nore nearly approeches tho normad erowth ourve of the control antmals than dues the growth surve of tine rals on the canned splnach. (Chart I).

It wrs onsluded that vitamin B was prosant to some oxtent in cooked kalo erouns. Posalbly this food was rloher in on of tho vitumin B "complexen" or that cooked kale lost some of the potency of the vitamin F fraction if 1 t wore present in the greon kelo.

In order to asourtain which fraction was moro abundent, if a in the cooked kgle as consumed by the human race, moro elaborate experimontal program was outlined and the work cerried on from fpril 29 to July $1,1929$. 
Aocording to chert II, kalo groens show better growth curve tilan spinach, but evidently the B fraction present in kalo greens has not been supplemented by the addition of the vitamin $G$ fraction in the form of auto-claved yeast as has the control of whole wheat plus auto-claved yeast ana, thereforo, from compar1son of the deta on diets $\# 6, \# 9$ and $\# 10$ in Chert II, the rets on det 6 if reduced to imple terms, means o(kale) plus o (auto-olaved yeast) wl thout the resultant normal growth curve. llowever, it may also be observed from this chart that vitamin 1 s not laoking entirely.

Chart III show kale groons and basal diet with a bettor growth ourve resulting. Vitamin B is not as yot sup lomented by 1 ts complementary fraction to ylold a normal growth ourvo as in the control diet $f 7$. The apinaon diet $\# 8$ is at1li taising havy toll. No doathe oocurred in the dlot with kale gro ns.

Whe Improvomont of the growth ourves in Chart IV are probably due to the addition of whole wheat to all three dets. Oranting that the whole wheat may have present some vitamin $G$ which would supplement the ourve representing the crowth of the animals on kale greons, diet $/ 5$ consisting of kalo ereons plus wolo wheat plus the basal dlet, shows greater growth than the control, diet /9 sonsidting of whole whoat plus 
auto-deved yeast plus basel dist, whloh clearly indioates that kale erouns is woll sup lemented by the wole wheat end is 1 tsolf potent in the opposite, thermo-stable foctor, vitamin a since the growth arve of the control diet $\frac{H}{79}$ is nuch less advanoed. Another contrat may be observed in the study of Che rt $\# 6$.

hverago gain for

experimental period.

DLet \#10--Spinach, ACY* B, D. $\quad 13.8$

Diet \# 9-- knole whert, AC X, BD 79.0

Die $\mathrm{t} \#$ 6-Kale, A. C. Y., B. D. 4.6

Det \# 7-nhole whent, B. D. 82.2

Llet $\# 8--1 . C$. Y., B. D. 0.41088

Dlet 4--Lale sind B. D. 33.5

Diet \#11--Sp1naoh, holo wheat 74.0

Dlet \#--Whole vhent, B. D., A. C. $\mathbf{7 9 . 0}$

Dlet \# 5o-Kale, Whole whent, D. D. 88.7

- = outo-cleved yoast

- = basal diot

In 11 the diets listed outeining kale greens, there 1s a gain in woight. Kalo greons supplemented by autoclaved yongt or vitamin $G$ shows an everage gain of 4.6 grams for the group. Splnach supplemented by auto-claved yeast show un average gain of $13.8 \mathrm{grams}$ for the group. 
Kale groens as the souroo of vitamins $F$ and $G$ show on averae ef in of $33.5 \mathrm{grrms}$ for the group. The control, wole what plus sutocisved yonst as the source of vitamirs $F$ und a rospootively shows en sverage gain of 79.0 grama for the eroup whlle kale greons and whole whoat, the apperent suroo of vitamins $G$ and $P$ respoct-

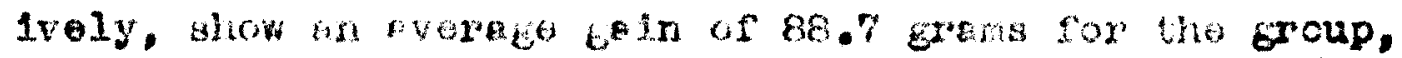
a difference of 9.7 erans betwo hole supplemanted by whole wheat and tho control det, wiole whent supilemented by nuto-chaved yosat, the known source of the vitamins $F$ enc a robpectively 27.

In chayt 1 , noto the followine casas of destho roduood when kalo is present: Drot $/ 6$ the numiver of pata at the boginning of the exparinutal pertod are 5, the number aurviving thia por:oa, 4. Diat /8 same vithout kalo, number of $x^{\text {te }}$ et tho boglning of the experimunte I perloi aro 5, nunbor surviving this poriod, 2. The periol of the letter 1s longer, but the deaths oocur arzly in the perlod. Dlet 12 , number of rats at the beglnning of tho perlod 4, nuinoer surviving the pertod 0 , 


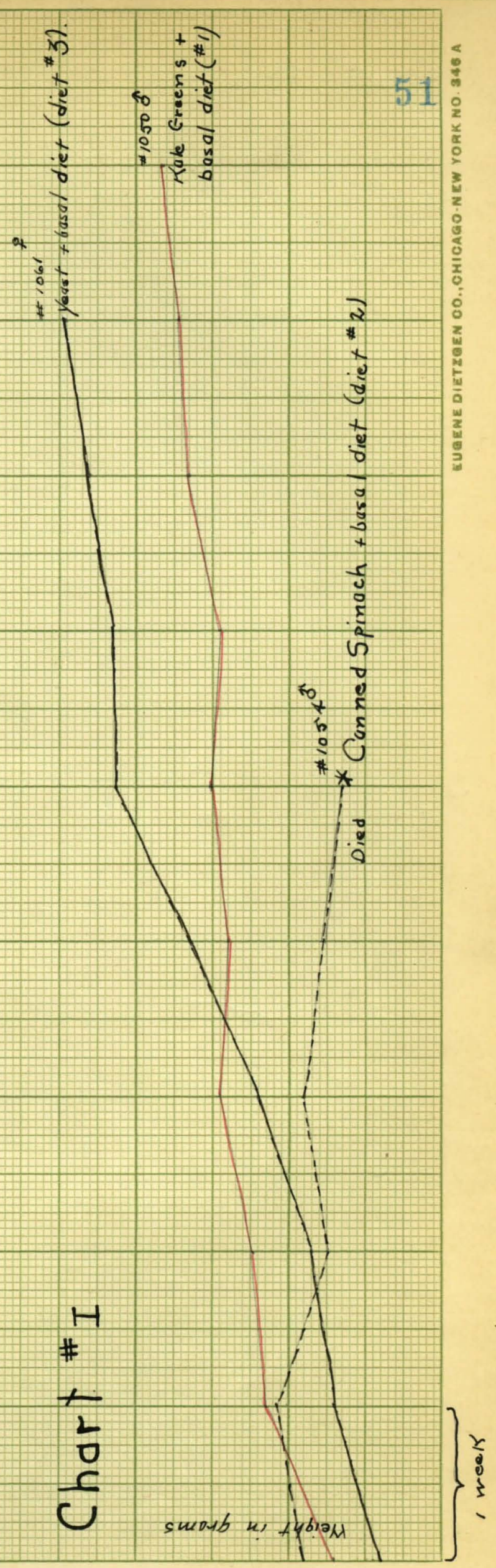

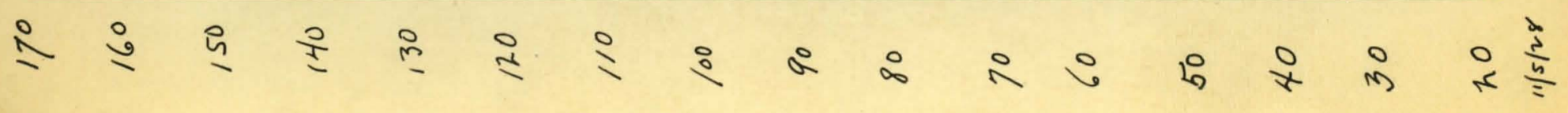




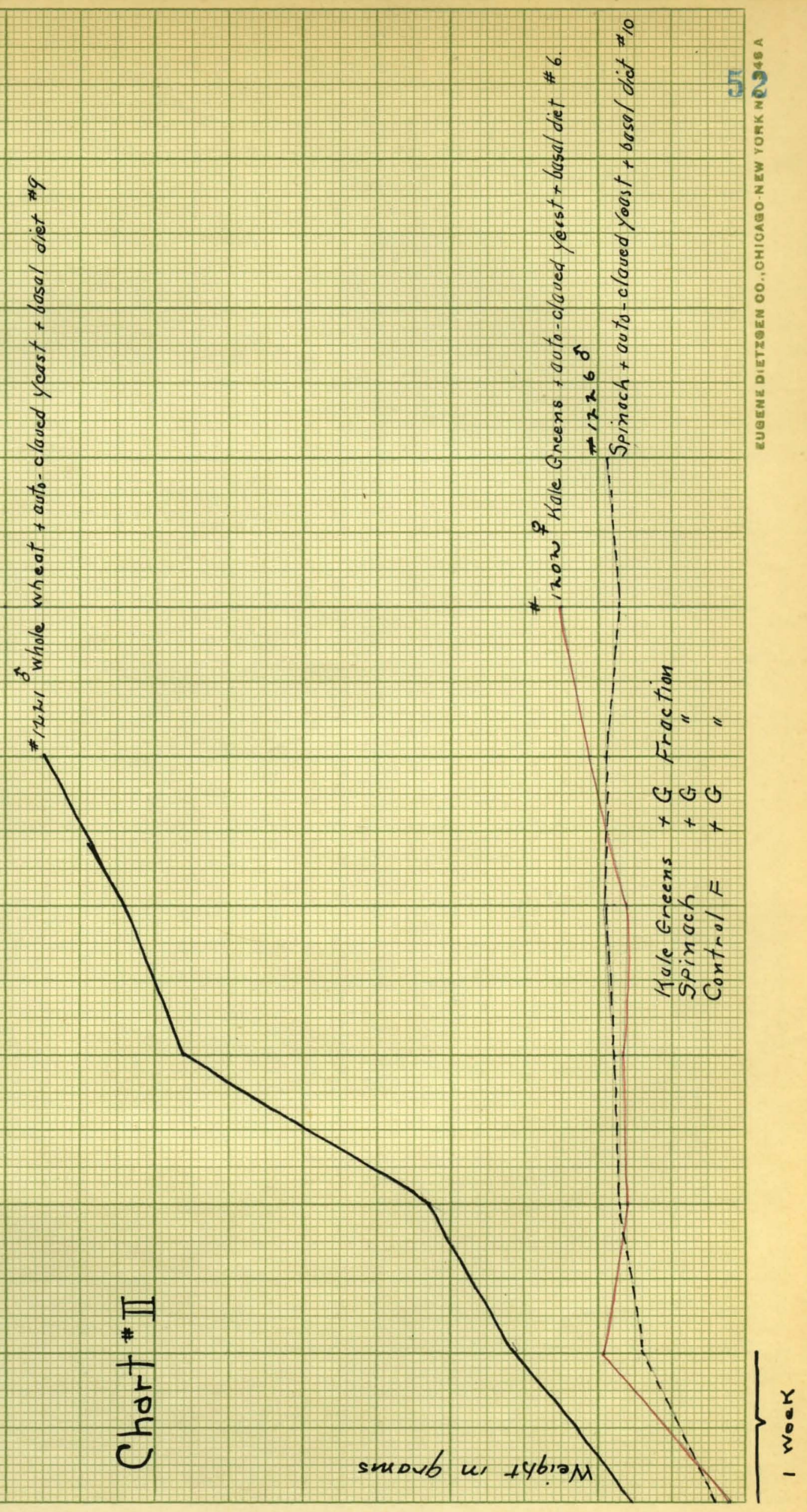

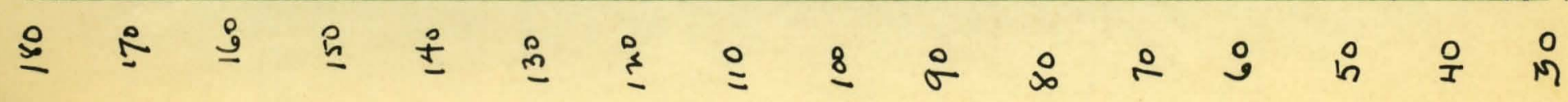




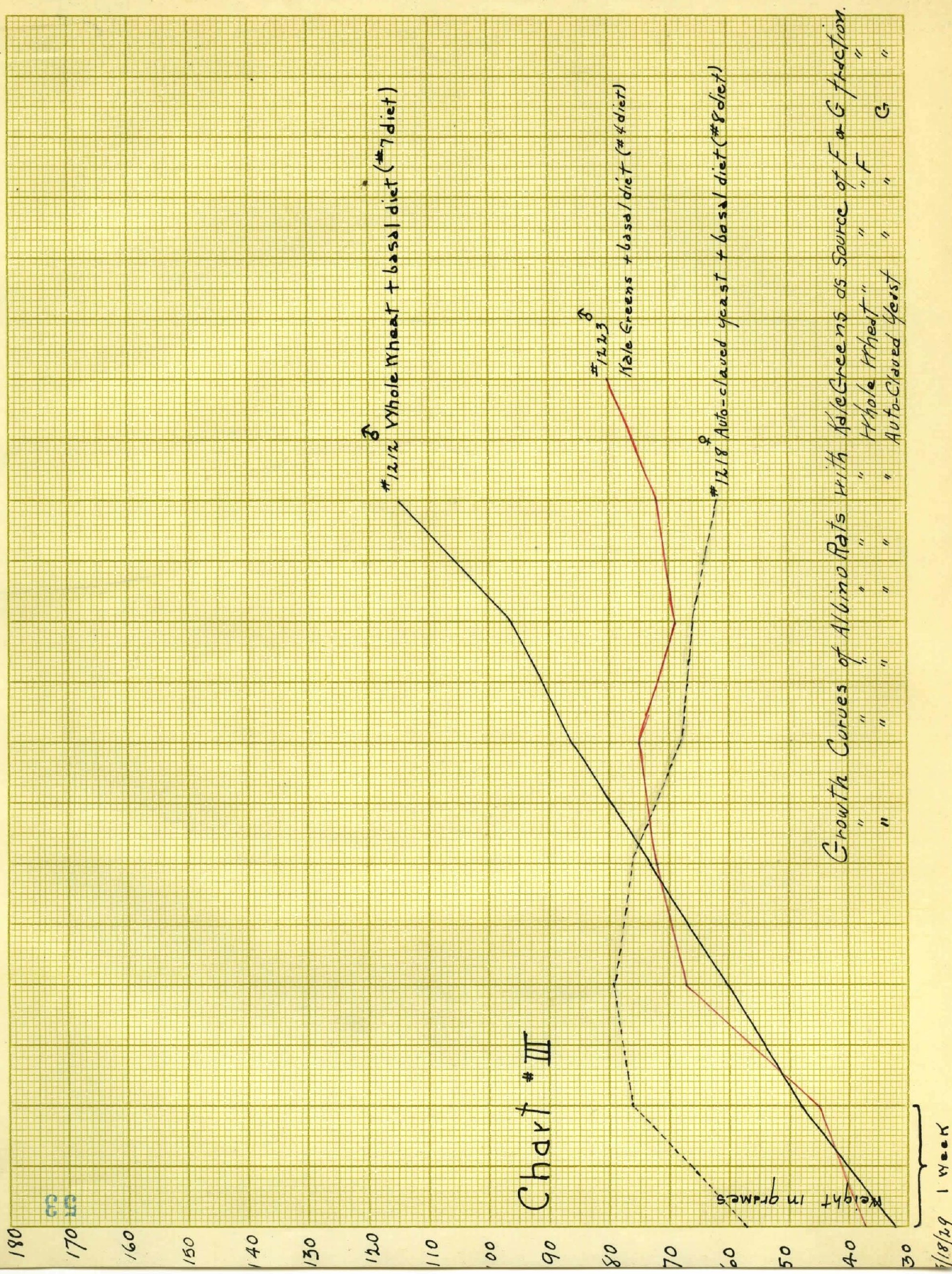




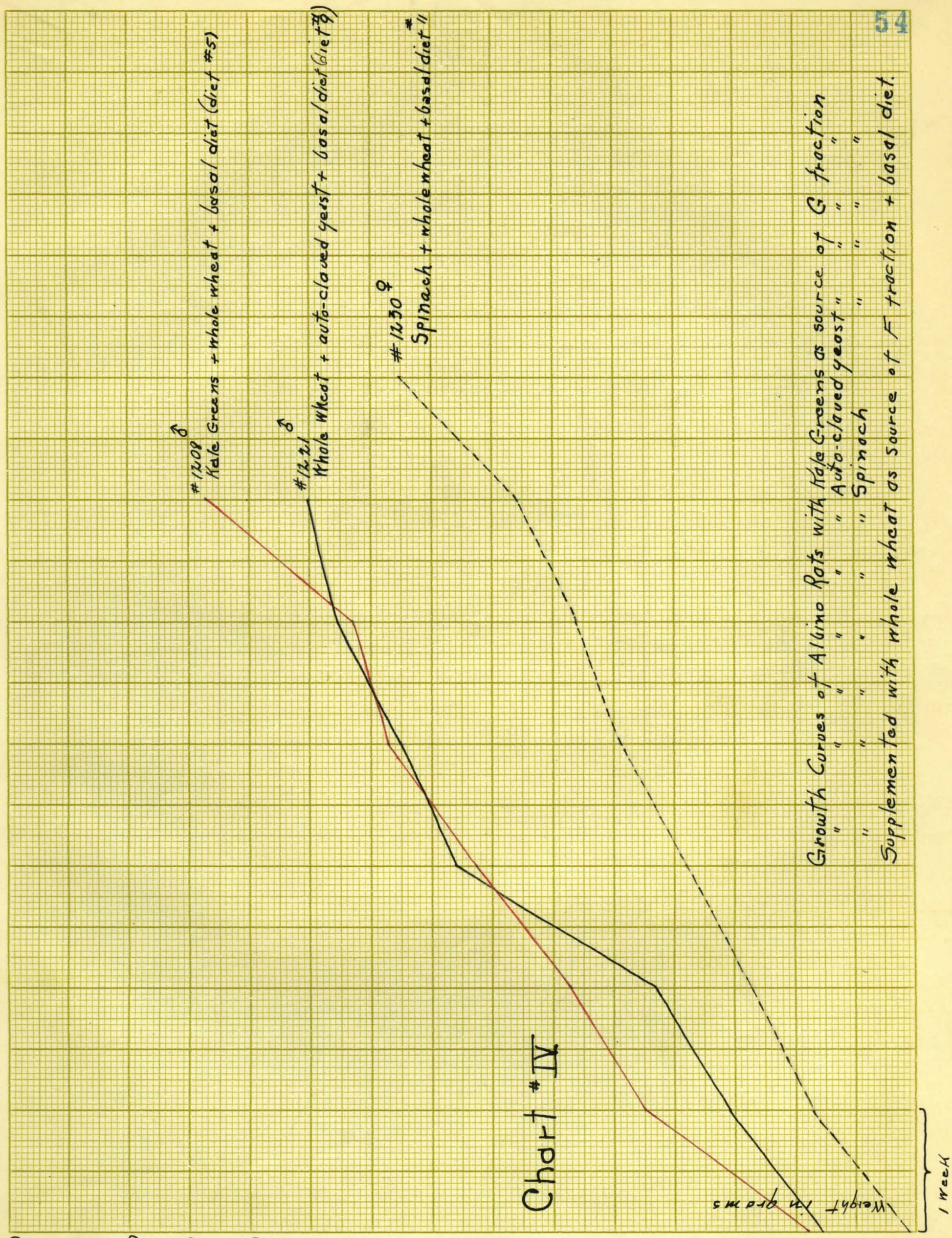

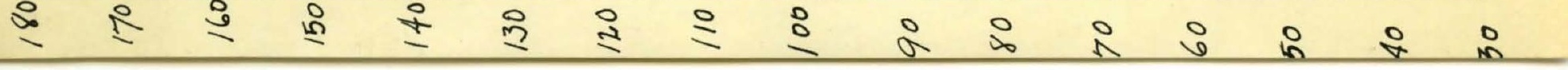


Welghts

Chart $\$ 6$

Diet \#1

In1t1al Wt. Final Wt.

Gain

Average gain of Rat Noa. in grams

in grams

gms

the group gmo

$\mathrm{Kalo,b} \cdot \mathrm{d}$

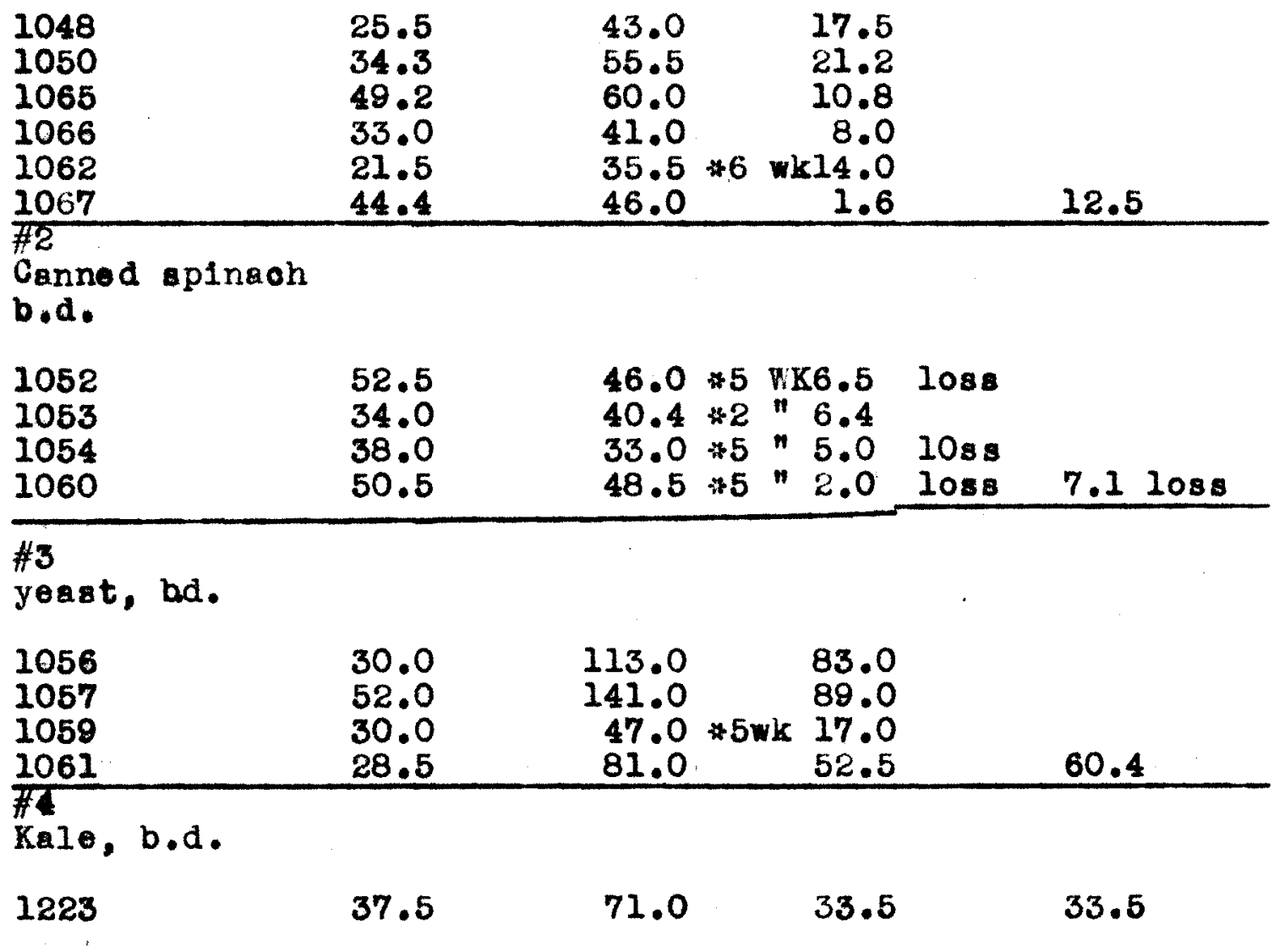

\#5

Kale

Wh wheat,b.d.

\begin{tabular}{|c|c|c|c|c|c|}
\hline $\begin{array}{l}1206 \\
1207 \\
1208 \\
1209 \\
1210\end{array}$ & $\begin{array}{l}74.5 \\
76.5 \\
48.0 \\
44.0 \\
51.5\end{array}$ & $\begin{array}{l}162.0 \\
142.0 \\
147.0 \\
133.0 \\
154.0\end{array}$ & $\begin{array}{r}87.5 \\
65.5 \\
99.0 \\
89.0 \\
102.5 \\
\end{array}$ & & 88.7 \\
\hline \multicolumn{6}{|c|}{$\begin{array}{l}\# 6 \\
\text { Kale } \\
\text { auto-01 yeast, b.d. }\end{array}$} \\
\hline $\begin{array}{l}1201 \\
1202 \\
1203 \\
1204 \\
1205\end{array}$ & $\begin{array}{l}43.2 \\
32.5 \\
55.0 \\
69.7 \\
68.0\end{array}$ & $\begin{array}{l}45.0 \\
54.5 \\
64.5 \\
44.5 \\
83.0\end{array}$ & $\begin{array}{r}1.8 \\
22.0 \\
9.5 \\
25.3 \\
15.0\end{array}$ & $108 \mathrm{~s}$ & 4.6 \\
\hline
\end{tabular}




\section{Chart \#6 (continued)}

Diets \& Initial Wt. Final Wt. Gain Average gain Rat Nos. In grams in grams in gms. of group (gms)

\#7

Wh whost, b.d.

1211

1212

1213

1214

1215

\#8

$\begin{array}{lll}29.8 & 122.0 & 92.2 \\ 32.0 & 115.0 & 83.0 \\ 71.5 & 141.0 & 69.5 \\ 59.0 & 136.0 & 77.0 \\ 68.5 & 158.0 & 89.5\end{array}$

82.2

Auto-claved yeast, b.d.

\begin{tabular}{|c|c|c|c|c|c|}
\hline $\begin{array}{l}1216 \\
1217 \\
1218 \\
1219 \\
1220 \\
\end{array}$ & $\begin{array}{l}41.0 \\
67.0 \\
57.8 \\
24.0 \\
33.5 \\
\end{array}$ & $\begin{array}{l}37.5 * 5 \mathrm{wk} \\
58.0 \\
62.5 \\
26.5 * 3 w k \\
39.6 * 4 \mathrm{wk}\end{array}$ & $\begin{array}{l}4.5 \\
9.0 \\
4.7 \\
2.5 \\
6.1 \\
\end{array}$ & $\log _{n} 8$ & $0.44 \quad 1088$ \\
\hline \multicolumn{6}{|c|}{$\begin{array}{l}\text { \#g } \\
\text { Wh wheat, auto-cl } \\
\text { yeast, b.d. }\end{array}$} \\
\hline $\begin{array}{l}1221 \\
1222\end{array}$ & $\begin{array}{l}34.0 \\
45.0\end{array}$ & $\begin{array}{l}130.0 \\
107.0\end{array}$ & $\begin{array}{l}96 \\
62\end{array}$ & & 79.0 \\
\hline \multicolumn{6}{|c|}{$\begin{array}{l}\text { mo } \\
\text { Splnach, auto-ol } \\
\text { yeast, b.d. }\end{array}$} \\
\hline $\begin{array}{l}1224 \\
1225 \\
1226 \\
1227\end{array}$ & $\begin{array}{l}32.0 \\
18.0 \\
33.0 \\
31.0\end{array}$ & $\begin{array}{c}44.0 \\
\text { weakling died } \\
48.0 \\
45.5\end{array}$ & $\begin{array}{l}12.0 \\
15.0 \\
14.5\end{array}$ & & 13.8 \\
\hline \multicolumn{6}{|c|}{ Spinach, wh wheat, b.d. } \\
\hline $\begin{array}{l}1228 \\
1229 \\
1230 \\
1231 \\
1232 \\
\end{array}$ & $\begin{array}{l}32.0 \\
29.0 \\
31.0 \\
33.0 \\
34.0 \\
\end{array}$ & $\begin{array}{r}101.0 \\
105.0 \\
105.0 \\
97.0 \\
110.0 \\
\end{array}$ & $\begin{array}{l}69.0 \\
76.0 \\
74.0 \\
61.0 \\
85.0\end{array}$ & & 74.0 \\
\hline
\end{tabular}


Chart \#1

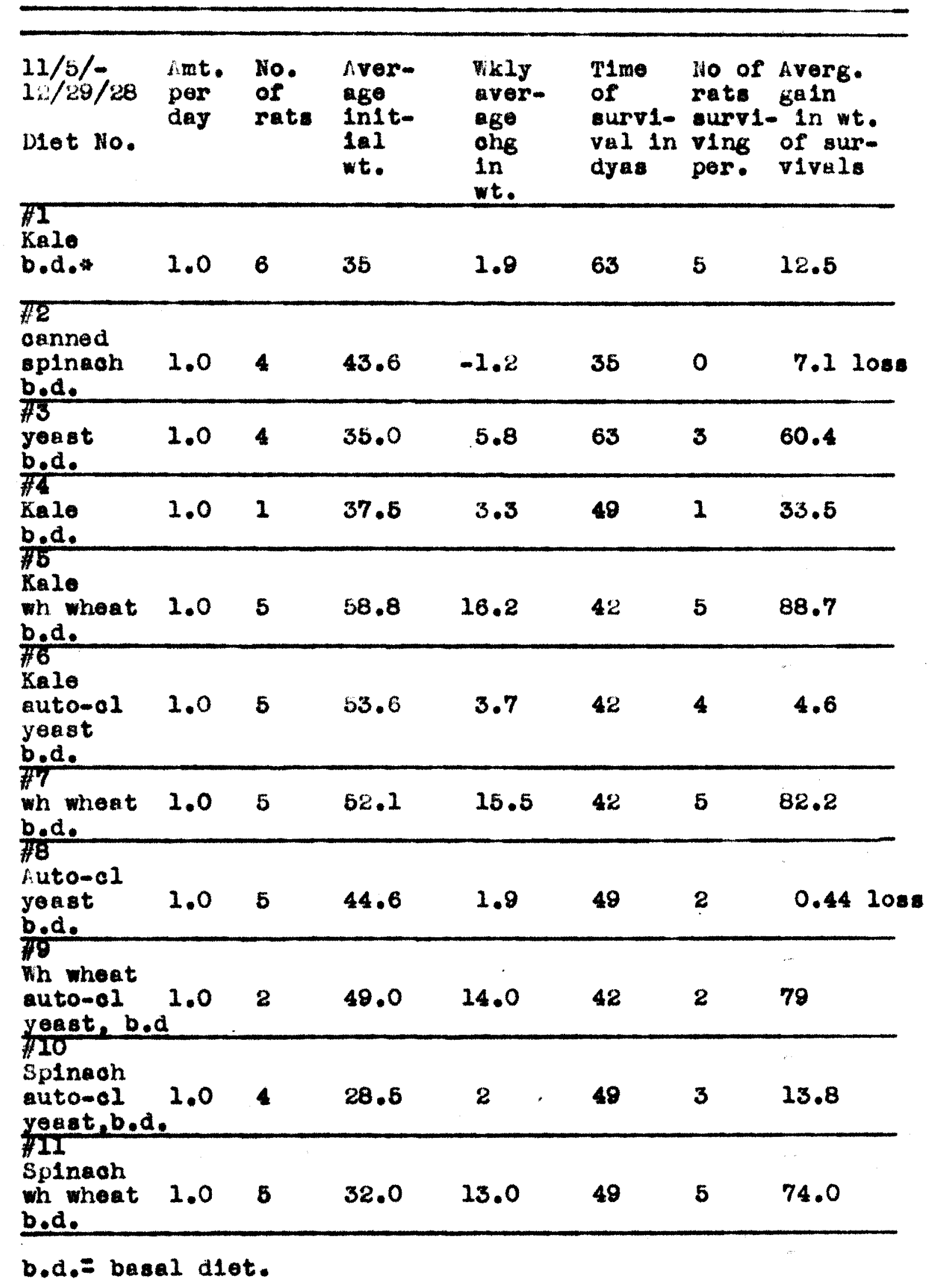




\section{SUL:MARY}

1. Death does not ocsur in tho albino rat when the sole souroe of vitamin B is cooked knle greens.

2. When cooked kale greons are supplemented by whole wheat to supply the vitamin F fraotion, a normal growth oxrve rosults with an average galn of 9.7 erims above the nornal control and 14.7 grams above the spinach control.

3. Cooked kale greens are potent in the thermoatable factor of vitamin B, vitauin $O$ and a fair source of the thermo-lajlle factor of vitamin $B$, vitamin 7 .

4. Cooked kalo greons are a better source of vitamin $P$ and an exceeding $1 y$ better saurce of the vitamin a fraotion of vitamin B than cooked spineoh. 
REFWHNCES 
1. Sherman, H. C., J. of Nutrition, 1, 191 (1928) NUTKITIONAL 3 TUUIPICANCE OF OUK MTESENT KNOV LEDGE OF THE WULTIPLS NATURE OF VITHIN B.

2. Fmmett, $h$. $\nu$. and Luros, $G, 0 .:$ MATR-SOLUBLE VITAMIN, I. Are the antinouritic and the growth-promoting water-solublo vitamins the ange? J. B102. Chem. 43, 265, (1920).

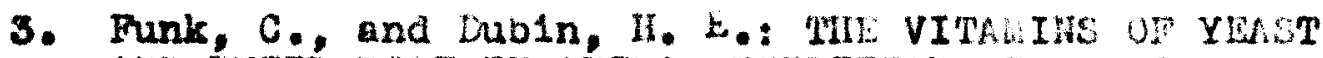
AiL WHETK FOLE IN MAIKAL NUTRITION. PrOC. SOo., Fxpet1. 3101. 1ed. 19, 15 (1921).

4. Levene, $k$, , tuhlfold, H., TIE IDFir ITY OK NONIDHNITY OF ADINFULITIC AN W DR-SOLUBLE B VIThkIns. J. B101. Whom., 57, 341-8 (1923).

5. Mocollum, L. V., Sima ds, Nine, Becker, rrestino

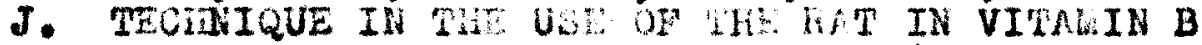
STUDIEs. J. B101. Chem. 63, 547-51 (1925).

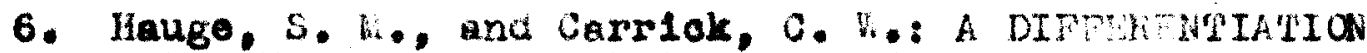

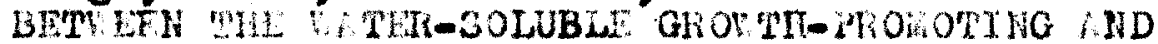

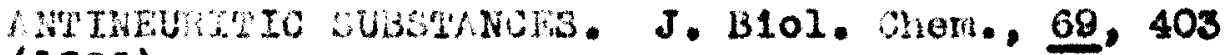
$(2926)$.

7. Smith, W. I., and lendriok, F. U., Sxas NuTHIII

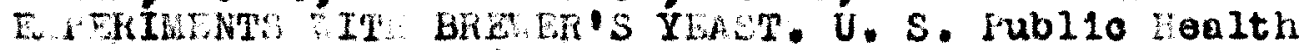
Rieports, 41, 201-7 (1926).

8. Selde11, tharton: CONCWMR PEN MNTMEUIIIC VIIA-

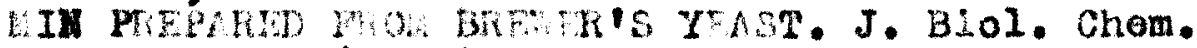
67. 693-600 (1926) of C.A. 17. 129.

9. Goldberger, J., and L1ll1e, h. D., Wheoler, $C_{.} \Lambda_{.}$,

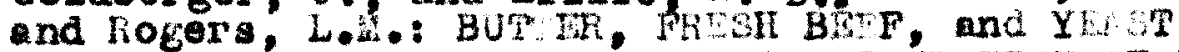

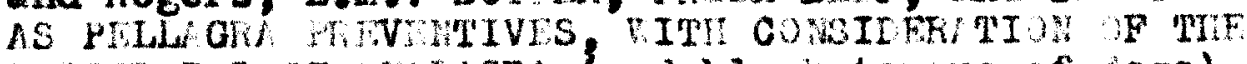

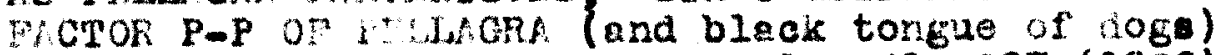
To VIThMIN B. U.S. Hubl10 Jealth 41, 297 (1926)

10 Goldberger, J., and lanner, F. F.: is SPUY of lHE

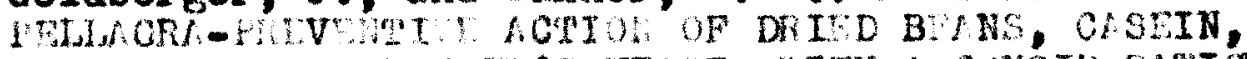

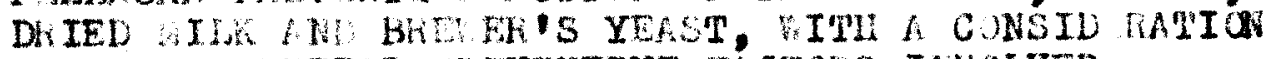

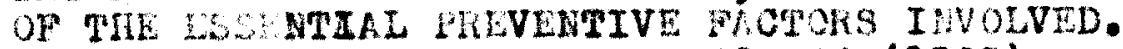
U. S. Publio Iealth Feports 40, 54 (1925)

11 Salmon, $Y$. D., THE HA ISTENCE OF TWO RCIIV FATORS IN THE vITAKIN B OódLX. J. B101 Chem. 73, 483-97 (1927). 
12 Chick, H., and Kosooe, H. H.: ON IIL COWOSITE NATE OT THE VIT R-SOLUBLL B VIIAMIN. J. B10ohem., 21. $698(1927)$.

13 Hasean, $\Lambda$, and Drummond, J. C. PHYSIOLOGICAL FoLF OF VITAIS B. IV. Relation of oertain dietary factors in yoart to growth of rats on diets rion in protein. Blookom. J. 21, 653 (1927).

14 Pal mer, L. S., and Kennedy, Cornel1a, IIIF FUHDA-

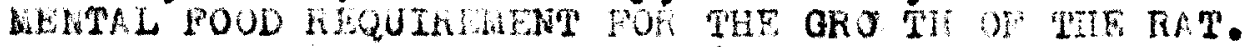
J. B101. Chom, 74, 591-611 (1927).

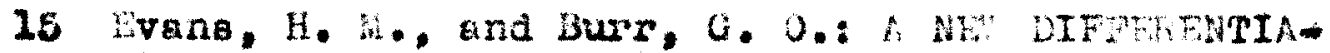

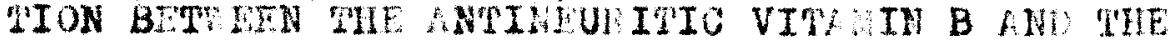

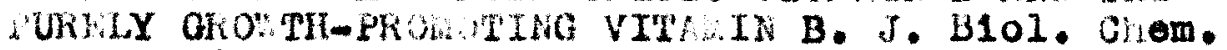
77. $231(1928)$.

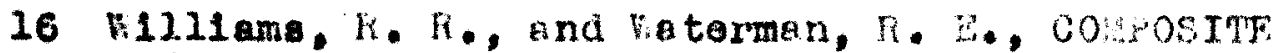
NATUKE OF VITfiLN B. Proc. Soo. Txpti. Biol. Hed., 25. $1-3(1927)$.

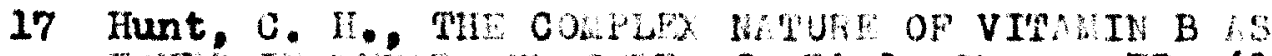

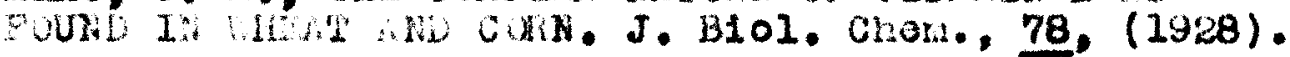

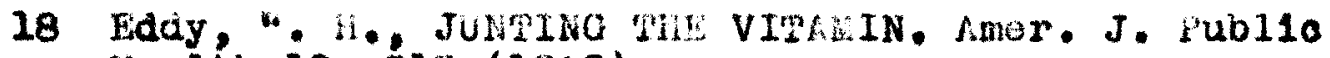
Health 18, 313 (1928).

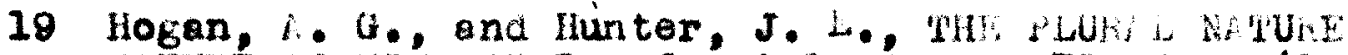
WATHE OF VIThM1H B. J. B101. Chom, 78, 433, (1928).

20 Sheman, II. C., Mechrthur, E. I. LABORWTHY WLUOTS

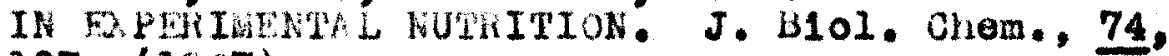
$107(1927)$.

21 Lduy, H. A., Kohman, E. ., Ha111day, Ye111e, VIThIS IH CANITD FoODS VII., J. Ind. Tng. Chem. 21. $347,(1920)$.

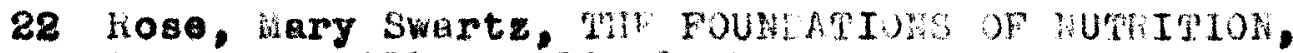
Text, oli1lan, $470,1927$.

23 Ferry, E. L., Lab. Toohnique of Experimental Animis. J. Lab. C11n. Hed. V, 735 (1920).

24 Oaborne, I. D., Mendel, L. B., SALT HITUK, J. B1ol. Chem. 37, 572, ( I 19):

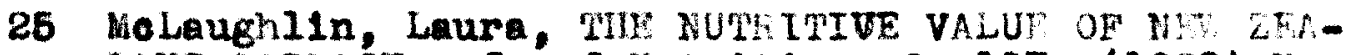
LND SHIMACH. J. of Nutrition, 2, 197, (1929) Nov.

26 Sherman, H. C., Burt1a, K. P. COmERISON OF HLS

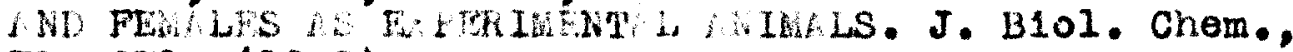
78. 671 (1928). 
27 Benediot, F. C., MoLood, G., TH: IMAT PTIODUCTION OF TIV libINo Rh. T. II Influenoe of Fnvironmental Temperature. J. Nutrition, 1, 367, (1929).

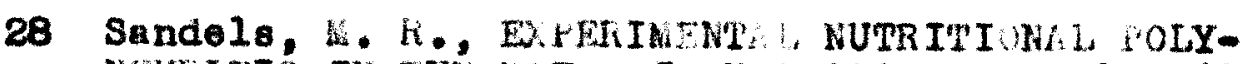
NEUFIIIS IN THE KiT. J. Nutrition, 2, 412, (1830) 